\title{
The formation of the development model of the innovative industrial cluster and methods for evaluating its economic effectiveness
}

\author{
L.A. Suvorova ${ }^{1, *}$, and L.L. Zaushitsyna ${ }^{1, *}$ \\ ${ }^{1}$ Economics department, Vyatka State University, Kirov, Russia
}

\begin{abstract}
The cluster approach is considered by the authors as the tool to ensure the accelerated development of the country's industrial complex. In the article the authors examine the problem of forming the model of the cluster development in high-tech sectors of industry and the methods for evaluating its economic effectiveness. Unlike traditional approaches, the authors of the article identify a cluster unit as the main structural element of the development model of the innovative industrial cluster. They think that a cluster unit is one member of the cluster (i.e.one enterprise). This point of view is differed from modern scientists`opinion, who view a cluster unit as the complex of enterprises operating within cluster units. The purpose of the study was the development and the economic evaluation of the model of the cluster development. In this research the authors examined the cluster of industrial biotechnologies. They have developed and proposed the model of the development of the cluster of industrial biotechnologies: the Non-commercial partnership (NP) "The biotechnology cluster of the Kirov region". This model takes into account the peculiarities of the innovative production. The authors have calculated the absolute and relative effect from clustering taking into account the effectiveness and profitability indicators of the cluster units activities within the cluster in question and the evaluation of the project activity of the cluster. Thus the authors have proved the economic effectiveness of the proposed model of the cluster development. The received research results allow us to conclude that the designed model of the development of the NP "The biotechnology cluster of the Kirov region" provides a steady growth trend of positive economic effect from the corporate activities of the enterprises within the cluster and increase in the region's competitiveness in the production of high-tech industrial products.
\end{abstract}

\section{Introduction}

Nowadays the Russian economy aims at ensuring the economic security and independence of the country. To achieve this goal is possible by solving two main problems. They are: the transition to the innovative way of development and the acceleration of introducing the Import Substitution Programme. These facts form the strategic task for the industrial complex. This task is to increase the production efficiency in the industrial sector of economy.

The defined aims and tasks are characterized by the following main problems. Firstly, the resources are limited. Secondly, the relationships between business entities, partners and consumers of industrial products are complex. Thirdly, there is the lack of efficiency of the market regulation of high-tech industrial products. We think that these problems can be solved through using the cluster approach for accelerating the rate of developing the country's industrial complex [1].

During the strategic development of the economy clusters become one of the elements in the complex mechanism of the new industrial policy of the state. The strategic development of innovative industrial clusters increases the chances of achieving stable positive rates of the country`s economic growth. If we consider the question at the regional level, the innovative industrial clusters and their strategic development are an effective tool to solve many problems connected with the socioeconomic development of the region [2].

Despite the considerable interest to the examined topic, one of the obstacles for the wider use of the cluster approach in the industrial complex of Russia is the poor study of both theoretical and practical aspects connected with the development model of clusters in high-tech industries and methods for evaluating its economic efficiency.

The complex of the described circumstances highlights the scientific relevance of the research topic.

\section{Defining the task of the research}

Despite the large number of scientific articles devoted to the formation and management of cluster development $[3,4,5]$, there are no studies in which the authors fully focus on designing the model of development of the innovative industrial cluster and methods for evaluating

\footnotetext{
*Corresponding author: larsuvorova@mail.ru
} 
its economic effectiveness, that are adopted to the conditions of the Russian regions' economy.

At the same time the analysis of the existing works about the development of industrial clusters in foreign countries (Finland, Sweden, Denmark, Germany, Norway, Netherlands) $[6,7,8]$ and in Russian regions $[9,10,11,12]$ led to the following conclusions. They are: 1) the level of clustering in Russian industry is quite low, it significantly falls behind the analogous indicator of the European countries; 2) the national characteristics of industrial policy largely determine the direction of cluster initiatives; 3) it is impossible to create an effective development model of the cluster without the financial and economic, technical and technological, information-communication and other interactions between the participating enterprises; 4) to assess the economic effectiveness of the cluster you must take into account the peculiarities and the main indicators of the development of individual enterprises participating in the cluster $[13,14]$.

\section{The developing of the model of development of the indastrial cluster and the evaluation of its efficiency: methodical bases}

According to the authors, an innovative industrial cluster is a quasi-integrated structure consisting of cluster of units, connected by subordinated links.

The model of the development of the innovative industrial cluster is a process including the sequence of actions of cluster units and which allows you to obtain positive economic results from cluster activities. The sequence of actions of cluster units is strictly regulated and it consists of three levels: the innovation designing, production and commercialization of innovations and scaling of innovations.

Unlike traditional approaches, the authors of the article identify a cluster unit as the main structural element of the development model of the innovative industrial cluster. They think that a cluster unit is one member of the cluster (i.e.one enterprise). This point of view is differed from modern scientists opinion, who view a cluster unit as the complex of enterprises operating within cluster units [15].

While developing the model of development of the innovative industrial cluster the authors of the article paid special attention to the following facts:

1) Firstly, when you form an innovative industrial cluster it is neccessary to take into account the positions of economic theory (A. Marshall [16], M. Porter [17], M. Enright [18], O. Solvell [19]). These positions point out that specialized industries tend to be concentrated geographically and to form clusters, i.e. the community of enterprises of closely related industries, that contribute to the growth of competitiveness of each other at national and international markets.

2) Secondly, it's necessary to take into account the Resolution position of the Russian Federation Government № 779 "About industrial clusters and specialized organizations of industrial clusters". According to this position the purpose of creating an industrial cluster is to create the complex of stakeholders acting in one field of industry, and that are related to the particular area due to the territorial nearness and the functional dependence, and that are situated on the territory of one subject of the Russian Federation or on the territory of several subjects of the Russian Federation, producing industrial products [20].

3) Thirdly, it's necessary to consider the innovative industrial cluster as a complex open system, the subjects of which are the manufacturing and service sectors, market infrastructure, educational, scientific and financial spheres; partners, relevant government structures and consumers of the industrial complex products. These subjects are located in a particular area (a country, a state, a county, a district, municipality, etc.) and in addition to the territorial relationship, they also have financial-economic and technical-technological relationship [21].

And, fourthly, it is necessary to consider the management mechanism of developing the innovative industrial clusters as the use of legal, organizational, informational, administrative and economic tools for the purposeful influence on forming the stable long-term and mutually beneficial relationships between the manufacturing and service organizations of the industrial sphere, market infrastructure, education, scientific and financial institutions, other partners and competitors, government and municipal authorities, industrial products customers. This position ensures their effective functioning and development [22].

Creating the model of development of the innovative industrial cluster the authors of the article also took into account the following: a method of forming and the type of the cluster; the specifics of the relationship and the interests of its members; the availability of administrative and territorial boundaries; the level of interaction between participants; possibility, necessity and functionality of referring various socio-economic, socio-political, administrative and legal entities to the certain type and the level of the industrial cluster.

The authors propose a new content of the category "a cluster unit", which is considered as a structural and functional elementary unit in the innovative industrial cluster that performs certain tasks and contributes to achieving the goal of the cluster [21]. At the same time the authors classify cluster units into five types according to their functional purpose (Table I).

All cluster units of the innovative industrial cluster are in certain relations to one another, and this dependence has a character of subordination. The total synergetic effect from developing the innovative industrial cluster is formed by the following way: the innovation cluster units develop an innovative product (technology, etc.), then the production cluster units produce it, and the marketing cluster units sell this product. Technological and institutional innovative cluster units of the innovation industrial cluster has a supporting role as they are engaged in the supply of raw materials, the provision of transport services, advertising, as well as financial aid and insurance.

The distinctive features of the proposed structure of the innovative industrial cluster are the following. The first feature is the division of the cluster into five sublevels, which are located on the principle of inclusion: each subsequent sublayer includes the previous one, thus increasing the quantitative and qualitative characteristics of the cluster (see Table I). 
Table 1. The Structure of the Innovative Industrial Cluster.

\begin{tabular}{|c|c|c|c|}
\hline Level & $\begin{array}{l}\text { The name of } \\
\text { the sublevel }\end{array}$ & $\begin{array}{c}\text { The cluster unit } \\
\text { type }\end{array}$ & $\begin{array}{c}\text { The type of the } \\
\text { organizations of } \\
\text { the particular } \\
\text { level }\end{array}$ \\
\hline Core & $\begin{array}{l}\text { Innovation } \\
\text { infrastructure }\end{array}$ & $\begin{array}{l}\text { Innovation } \\
\text { cluster unit }\end{array}$ & \begin{tabular}{|l|} 
Organizations \\
developing \\
technologies \\
(research \\
institutes, \\
universities) \\
\end{tabular} \\
\hline \multirow[t]{2}{*}{ Centre } & $\begin{array}{c}\text { Industrial } \\
\text { infrastructure }\end{array}$ & $\begin{array}{l}\text { Industrial } \\
\text { cluster unit }\end{array}$ & $\begin{array}{l}\text { Enterprises } \\
\text { producing } \\
\text { innovative } \\
\text { products, created } \\
\text { on the basis of the } \\
\text { developed } \\
\text { technology }\end{array}$ \\
\hline & $\begin{array}{l}\text { Marketing } \\
\text { infrastructure }\end{array}$ & $\begin{array}{l}\text { Marketing } \\
\text { cluster unit }\end{array}$ & $\begin{array}{c}\text { Enterprises } \\
\text { engaged in selling } \\
\text { the products } \\
\text { developed on the } \\
\text { basis of new } \\
\text { technology }\end{array}$ \\
\hline \multirow[t]{2}{*}{ Periphery } & $\begin{array}{l}\text { Technological } \\
\text { infrastructure }\end{array}$ & $\begin{array}{l}\text { Technological } \\
\text { cluster unit }\end{array}$ & $\begin{array}{l}\text { Technologically } \\
\text { depended } \\
\text { enterprises }\end{array}$ \\
\hline & $\begin{array}{l}\text { Institutional } \\
\text { infrastructure }\end{array}$ & $\begin{array}{l}\text { The institutional } \\
\text { cluster unit }\end{array}$ & $\begin{array}{l}\text { Enterprises, } \\
\text { organizations and } \\
\text { institutions of the } \\
\text { institutional } \\
\text { structure }\end{array}$ \\
\hline
\end{tabular}

Secondly, in the proposed structure of the industrial cluster the authors have identified the core, which influence the cluster activity as a whole. As a result, the traditionally used approach to the structure of the cluster ("center-periphery") is transformed into the model "corecenter-periphery". This "core" consists of two types of subjects: entities that generate innovations and entities that develop innovations.

The authors also offer to create the model of development of the innovative industrial cluster on the principle of inclusion. The innovative industrial cluster is one part of the industrial sector of the country, therefore, the directions of its development should be developed in the same way as the priorities of the development of the national industry and the industrial complex of the region. Practically, this means that the development of the cluster unit is the primary component of the model of the development of the industrial cluster as a whole, which is one of the tools of the region's industrial complex development.

The implementation of the proposed approach to creating the model of development of the innovative industrial cluster can be realized through four stages (Table II).

The authors consider two groups of index of effectiveness to be the basis of the methodology for evaluating the economic effectiveness of the model of the innovative industrial cluster development.

The first group of the index of effectiveness consists of capital productivity, turnover ratio of current assets and labour productiveness. The second group includes different indicators of profitability: return on sales, return on fixed capital assets and return on current capital (there is the same number of evaluation indicators in each group). The proposed method of evaluating the model of development of the innovative industrial cluster is multifunctional. It allows to evaluate all the components of the innovation cluster and to obtain the objective economic results of its operations.

Table 2. Stages of Creating the Model of Development of the Innovative Industrial Cluster.

\begin{tabular}{|c|c|c|}
\hline Stage & Substage & $\begin{array}{c}\text { Characteristics of the } \\
\text { stage }\end{array}$ \\
\hline \multirow{5}{*}{ Formation } & $\begin{array}{l}\text { The formation of } \\
\text { the model of the } \\
\text { industrial cluster } \\
\text { development }\end{array}$ & $\begin{array}{l}\text { Setting the general purpose } \\
\text { of the industrial cluster } \\
\text { development as a whole } \\
\text { and of its cluster units. } \\
\text { Defining the target } \\
\text { indicators of the cluster } \\
\text { development as a whole } \\
\text { and of its cluster units. }\end{array}$ \\
\hline & $\begin{array}{l}\text { Defining directions, } \\
\text { spheres and } \\
\text { activities of the } \\
\text { biotechnology } \\
\text { cluster }\end{array}$ & $\begin{array}{l}\text { Evaluating the } \\
\text { effectiveness of each } \\
\text { direction of the cluster } \\
\text { activities. The financial } \\
\text { evaluation of the potential } \\
\text { value of the whole cluster } \\
\text { and of its cluster units in } \\
\text { particular. Determining } \\
\text { predictive values of the } \\
\text { market share, i.e. the sales } \\
\text { volume and the volume of } \\
\text { investments to achieve it. }\end{array}$ \\
\hline & $\begin{array}{l}\text { Defining the } \\
\text { composition of the } \\
\text { biotechnology } \\
\text { cluster, the } \\
\text { definition of } \\
\text { development } \\
\text { alternatives }\end{array}$ & $\begin{array}{l}\text { Making up alternative } \\
\text { business portfolios based } \\
\text { on the methods of financial } \\
\text { modeling. The } \\
\text { development of financial } \\
\text { indicators characterizing } \\
\text { the effectiveness of } \\
\text { alternatives. The } \\
\text { determination of the } \\
\text { optimal composition of the } \\
\text { cluster areas, in terms of } \\
\text { the optimum ratio of return } \\
\text { and risks. }\end{array}$ \\
\hline & $\begin{array}{l}\text { Defining the role of } \\
\text { the cluster "core", the } \\
\text { degree of } \\
\text { centralization of } \\
\text { management } \\
\text { functions and the } \\
\text { degree of } \\
\text { independence of } \\
\text { cluster units. }\end{array}$ & $\begin{array}{l}\text { The determination of the } \\
\text { status of the industrial } \\
\text { cluster "core", the degree of } \\
\text { centralization of } \\
\text { management functions, the } \\
\text { level of control. }\end{array}$ \\
\hline & $\begin{array}{l}\text { The formalization of } \\
\text { the developed model } \\
\text { of the cluster } \\
\text { development. }\end{array}$ & $\begin{array}{l}\text { The development of the } \\
\text { system of internal } \\
\text { regulations. The } \\
\text { development of internal } \\
\text { regulations of cluster } \\
\text { management. Creating the } \\
\text { relevant positions, } \\
\text { regulations and documents. }\end{array}$ \\
\hline Realization & $\begin{array}{l}\text { The implementation } \\
\text { of the common goal } \\
\text { of the } \\
\text { biotechnological } \\
\text { cluster. }\end{array}$ & $\begin{array}{l}\text { The implementation of the } \\
\text { cluster development model. } \\
\text { Creating the relationship of } \\
\text { the model of the cluster } \\
\text { development with the } \\
\text { current operational } \\
\text { management. }\end{array}$ \\
\hline Control & $\begin{array}{l}\text { Monitoring the } \\
\text { implementation of } \\
\text { the model and the } \\
\text { analysis of } \\
\text { deviations. }\end{array}$ & $\begin{array}{l}\text { Organization of the internal } \\
\text { control. The financial } \\
\text { analysis. Correcting target } \\
\text { solutions, update plans, } \\
\text { specification of forecasts. }\end{array}$ \\
\hline Evaluation & $\begin{array}{l}\text { Evaluating the } \\
\text { effectiveness of the } \\
\text { created model of } \\
\text { development. }\end{array}$ & $\begin{array}{l}\text { Evaluating the effectiveness } \\
\text { of the created model of the } \\
\text { cluster development through } \\
\text { targeted economic } \\
\text { indicators. }\end{array}$ \\
\hline
\end{tabular}




\section{The Development Model of the Cluster of Industrial Biotechnologies}

The concept of the development of the cluster of industrial biotechnologies in the Kirov region, e.g. the Non-Commercial Partnership "The biotechnology cluster of the Kirov region is realized on the basis of the proposed approach to creating the model of development of the innovative industrial cluster for the period 2015'2020. The Non-Commercial Partnership "The biotechnology cluster of the Kirov region" (NP "BTC") has been operating in the Kirov region since 2009. This is a classic example of the cluster formed "from below", i.e. it is the union of small businesses that have already experienced the "market testing", produced different products and united to maximize the synergetic effect. Members of the biotechnology finance and control their projects themselves. The NP "BTC" was developed with the support of the Foundation for Assistance to Small Innovative Enterprises in the scientific and technical sphere (Bortnik Fund) and with the assistance of subsidies allocated for the development of small businesses by the regional budget [23]. The priorities of the NP "BTC" are industrial biotechnologies in the field of bioenergy, agriculture, forestry and ecology.

The NP "BTC" is a quasi-integrated structure consisting of cluster units. Each cluster unit passes through certain stages of its life cycle: the initial stage, periods of growth, maturity and decline. In the proposed model of the cluster development the authors offer a set of specific actions for each cluster unit of the NP "BTC" (Table III).

Table 3. Types of Specific Actions for Cluster Units of the NP "BTC".

\begin{tabular}{|c|c|c|c|}
\hline $\begin{array}{c}\text { Stages of } \\
\text { the life } \\
\text { cycle }\end{array}$ & $\begin{array}{c}\text { Type of the } \\
\text { development tactics }\end{array}$ & $\begin{array}{c}\text { Types of } \\
\text { financial tactics }\end{array}$ & $\begin{array}{c}\text { Tactics } \\
\text { destinations }\end{array}$ \\
\hline $\begin{array}{c}\text { The initial } \\
\text { stage of } \\
\text { developm } \\
\text { ent or the } \\
\text { stage of } \\
\text { rapid } \\
\text { growth of } \\
\text { the cluster } \\
\text { unit }\end{array}$ & $\begin{array}{c}\text { The tactics of rapid } \\
\text { growth of: } \\
\text { - vertical clustering; } \\
\text { - horizontal or } \\
\text { conglomerate } \\
\text { diversification }\end{array}$ & $\begin{array}{c}\text { The support tactics } \\
\text { of the } \\
\text { accelerated } \\
\text { growth }\end{array}$ & $\begin{array}{c}\text { The accelerated } \\
\text { growth of the } \\
\text { potential of } \\
\text { forming } \\
\text { financial } \\
\text { resources }\end{array}$ \\
\hline $\begin{array}{c}\text { The stage of } \\
\text { maturity } \\
\text { of the } \\
\text { cluster } \\
\text { unit }\end{array}$ & \begin{tabular}{|c|} 
The tactics of intensive \\
growth: \\
- strengthening the \\
competitive position; \\
expansion of the market; \\
- improving products
\end{tabular} & $\begin{array}{l}\text { The tactics of } \\
\text { financial } \\
\text { ensuring of the } \\
\text { sustainable } \\
\text { growth }\end{array}$ & $\begin{array}{l}\text { Ensuring the } \\
\text { efficient } \\
\text { allocation and } \\
\text { use of } \\
\text { financial } \\
\text { resources }\end{array}$ \\
\hline $\begin{array}{l}\text { The } \\
\text { recession } \\
\text { or crisis } \\
\text { stage of } \\
\text { the cluster } \\
\quad \text { unit }\end{array}$ & $\begin{array}{c}\text { The tactics of reducing: } \\
\text { - structures; } \\
\text { - costs; } \\
\text { - transition to other } \\
\text { organizational forms; } \\
\text { - changes in activity area } \\
\text { of the company }\end{array}$ & $\begin{array}{c}\text { The anti-crisis } \\
\text { strategy, } \\
\text { aimed at high } \\
\text { mobility of using } \\
\text { the released capita } \\
\text { for the financial } \\
\text { stabilization of the } \\
\text { cluster }\end{array}$ & $\begin{array}{c}\text { Ensuring the } \\
\text { sufficient } \\
\text { level of } \\
\text { security }\end{array}$ \\
\hline
\end{tabular}

Evaluating the economic effectiveness of the proposed development model of the NP "BTC" was carried out in four stages. During the first stage the total activity results of the cluster units were evaluated. During the second stage the authors analyzed the activity results of the cluster in the context of its infrastructures, as well as in the context of its levels ("core", "center", "periphery") according to two groups of indicators used in the first stage (capital productivity, turnover ratio of current assets, labour productiveness; return on sales, return on fixed capital assets, return on current capital). Further, the authors have evaluated the project activities of the NP "BTC", as the effectiveness of the cluster as a whole depends on the effectiveness of the project activities of the cluster. At the same time, all the innovative cluster projects were divided into three categories: projects in progress, projects in the stage of beginning, projects in the waiting stage. According to project categories and the defined structure of project activities, the authors have evaluated the effectiveness of the projects in progress, taking into account the coefficient of cluster unit's participation in projects. During the fourth stage the authors carried out the calculation of absolute and relative effects from clustering. The positive absolute effect from clustering is expressed in the growth of value added, in absolute growth of the effectiveness indicators (capital productivity, turnover ratio and labour productiveness). And the positive relative effect is expressed in relative growth of the effectiveness indicators (capital productivity, turnover ratio and labour productiveness), and also in the positive dynamics of profitability indicators. The received results of evaluating the economic effectiveness of the proposed development model of the NP "The biotechnology cluster of the Kirov region" are presented in Table IV.

The realization of the proposed development model of the NP "The biotechnology cluster of the Kirov Region" will allow yield benefits in the form of value added on all cluster infrastructures. The results of implementing the given model will be: 1) the inclusion of all cluster units into innovation and project activity; 2) obtaining positive effects in the form of value-added per a cluster unit from a single innovative project; 3) the implementation of the development model will provide a steady growth trend of value added, i.e. the total synergetic effect resulting from the cluster activities. All of this will ensure the achievement of the development purposes of the industrial biotechnology industry in the Kirov region in terms of increasing the share of industrial biotechnology products in the structure of Gross Regional Product (GRP) to $1 \%$ by 2020 .

\section{Conclusion}

Summing up, we can conclude that the developed by the authors method for evaluating the economic effectiveness of the development model of the innovative industrial cluster is multifunctional. This method allows to evaluate all the components of the innovation cluster, to obtain the objective economic results of its activity. The implementation of the proposed development model of innovative industrial clusters will allow to yield positive effects in the form of value added on all cluster infrastructure and the steady growth trend of the total synergetic effect according to the results of the cluster activities as a whole. 
Table 4. Evaluating the Economic Efficiency of the Development Model of the NP "BTC" for the Period 2015-2020.

\begin{tabular}{|c|c|c|c|c|c|c|c|}
\hline Indicators & $\begin{array}{c}\text { Before } \\
\text { clustering } \\
2001-2009\end{array}$ & $\begin{array}{c}\text { After } \\
\text { clustering } \\
\text {, without } \\
\text { the } \\
\text { develop- } \\
\text { ment } \\
\text { model }\end{array}$ & $\begin{array}{c}\text { After } \\
\text { clustering } \\
\text {, with the } \\
\text { develop- } \\
\text { ment } \\
\text { model }\end{array}$ & $\begin{array}{l}\text { The absolute } \\
\text { effect from } \\
\text { clustering }\end{array}$ & $\begin{array}{l}\text { The absolute } \\
\text { effect from } \\
\text { clustering } \\
\text { based on the } \\
\text { development } \\
\text { model, }+/-\end{array}$ & $\begin{array}{l}\text { The relative } \\
\text { effect from } \\
\text { clustering, \% }\end{array}$ & $\begin{array}{l}\text { The relative } \\
\text { effect from } \\
\text { clustering based } \\
\text { on the } \\
\text { development } \\
\text { model, } \%\end{array}$ \\
\hline Revenue, in thousand rubles & 776667 & 1215520 & 1383620 & 438853 & 606953 & 156.50 & 178.15 \\
\hline Expenses, in thousand rubles & 719165 & 754148 & 764148 & 34983 & 44983 & 104.86 & 106.25 \\
\hline $\begin{array}{l}\text { The financial result, in thousand } \\
\text { rubles }\end{array}$ & 57502 & 461372 & 619472 & 403870 & 561970 & 802.36 & 107.31 \\
\hline Fixed capital, in thousand rubles & 1324589 & 1401786 & 1401796 & 77197 & 77207 & 105.83 & 105.83 \\
\hline $\begin{array}{l}\text { Current capital, in thousand } \\
\text { rubles }\end{array}$ & 86822 & 93113 & 93113 & 6291 & 6291 & 107.25 & 107.25 \\
\hline $\begin{array}{l}\text { The average number of manual } \\
\text { workers on the strength, men }\end{array}$ & 3619 & 4844 & 4844 & 1225 & 1225 & 133.85 & 133.85 \\
\hline Capital productivity, in rubles & 0.59 & 0.87 & 0.99 & 0.28 & 0.4 & 147.46 & 167.80 \\
\hline Turnover ratio, per year & 8.95 & 13.05 & 14.86 & 4.1 & 5.91 & 145.81 & 166.03 \\
\hline $\begin{array}{l}\text { Labour productiveness, in } \\
\text { thousand rubles per a man }\end{array}$ & 214.61 & 250.96 & 285.66 & 36.35 & 71.05 & 116.94 & 133.11 \\
\hline Profitability of sales, coefficient & 7.4 & 37.96 & 44.77 & 30.56 & 37.37 & 512.97 & - \\
\hline $\begin{array}{l}\text { Profitability of fixed capital, } \\
\text { coefficient }\end{array}$ & 4.34 & 32.91 & 44.19 & 28.57 & 39.85 & 758.29 & - \\
\hline $\begin{array}{l}\text { Profitability of current capital, } \\
\text { coefficient }\end{array}$ & 66.23 & 495.5 & 665.29 & 429.27 & 599.06 & 748.15 & - \\
\hline
\end{tabular}

\section{References}

1. O.V. Nesmachnyh, V.V. Litovchenko, Basic Research, 9(P.1), 162-165 (2014)

2. L.L. Zaushitsyna, L.A. Suvorova, Scientific Review, 6, 255-260 (2014)

3. T.V. Tsikhan, Theory and practice of management, 5, 74-81 (2003)

4. G.D. Boush, Economic science of modern Russia, 1, 40-49 (2011)

5. T.V. Mirolyubova, T.V. Larina, Kovalev, Patterns and factors of the formation and development of regional clusters: a monograph (Perm State Scientific and Research University, Perm, 2013)

6. Regional Clusters in Europe: European Commission Report, Observatory of European SMES. Enterprise Publications, 3 (2002)

7. PRO INNO Europe paper. The concept of clusters and cluster policies and their role for competitiveness and innovation: main statistical results and lessons learned, 9 (2008). http://www.clusterobservatory.eu.

8. The High Level Advisory Group On Clusters: The European Cluster Memorandum. http://www.innoclusters.ru/uploaded/docs/europea n_cluster_memorandum.pdf.

9. V.L. Abashkin, M.Yu. Goland, L.M. Hochberg, Pilot innovative territorial clusters in the Russian Federation (National Research University Higher School of Economics, Moscow, 2013).

10. I.V. Pilipenko, Proc. Annual Economic Report in 2008 of All-Russian public organizations "Business Russia".http://www.rsronline.ru/doc/norm/222.pdf.

11. E. Kutsenko, D. Tyumentseva, Problems of economy, 9, 93-107 (2011)
12. V. Abashkin, A. Boyarov, E. Kutsenko, Foresight, 3, 6, 16-27 (2012)

13. T.A. Khudyakova, Proc. International Congress on Interdisciplinary Behavior and Social Science 2015, 295-297 (2015)

14. T.A. Khudyakova, A.V. Shmidt, Proc. of The 26th International Business Information Management Association Conference, 1612-1616 (2015)

15. E.A. Udovik, N.A. Ovcharenko, S.B. Chetyz, Problems of Economics and Law, 1, 134-137 (2012)

16. A. Marshall, M. Marshall, The Economics of Industry (Macmillan, London, 1879)

17. M. Porter, Economic Development Quarterly, 1, 14, 15-34 (2000)

18. M. Enrghit, U. Staber, N. Shaefer, B. Sharma, Business Networks: Prospects for Regional Development, 190-213 (1996)

19. O. Solvell, Clusters-Balancing Evolutionary and Constructive Forces (Ivory Tower Publisher, Stockholm, 2009)

20. http://minpromtorg.gov.ru/common/upload/files/d ocs/Postanovlenie.pdf.

21. L.L. Zaushitsyna, The Innovative biotechnological cluster as the basis for achieving the country's regional potential (using the materials of the Kirov region): a monograph (the Vyatka State University, Kirov, 2015)

22. R.A. Schinova, L.A. Suvorova, L.L. Zaushitsyna, The Bulletin of the Ural Federal University, the section of Economics and Management, 14, 3, 457-474 (2015). 10.15826/vestnik.2015.14.3.027.

23. L.L. Zaushitsyna, L.A. Suvorova, T.V. Baibakova, Analysis of the conditions of formation, effective functioning and management of innovative technological clusters of the Kirov region (Kirov, Vyatka State University, 2015) 